\title{
Kjønns- og aldersforskjeller ved bruk av psykofarmaka
}

\begin{abstract}
Sammendrag
Bakgrunn. I Felleskatalogen er doseringen av legemidler oppgitt uten differensiering basert på pasientens kjønn. Dette til tross for at det for en del medikamenter er påvist farmakokinetiske forskjeller mellom kvinner og menn. Hensikten med studien var å undersøke kjønns- og aldersforskjeller i dosering og serumkonsentrasjon av psykofarmaka.
\end{abstract}

Materiale og metode. Dosering og serumkonsentrasjon av antidepressiver, antipsykotika og antiepileptika ble studert hos 1553 pasienter. I tillegg ble pasientenes alder og kjønn registrert.

Resultater. Eldre kvinner ( $\geq 65$ år) hadde noe lavere dosering av antidepressiver, men de hadde signifikant høyere serumkonsentrasjon enn yngre pasienter av begge kjønn. Antiderpressiver ble dosert relativt høyt i studiepopulasjonen, mediant antall definerte døgndoser var 1,5. Serumkonsentrasjon av antipsykotika og antiepileptika var ikke signifikant forskjellig for eldre og yngre pasienter.

Fortolkning. Studien kan tyde på at norske leger ikke tar nok hensyn til kjønn og alder ved dosering av antidepressiver.

\section{Kjell Petter Bøgwald}

kjellpb@extern.uio.no

Seksjon for psykiatrisk forskning og undervisning Diakonhjemmet Sykehus

\section{Ida Rudberg}

Senter for psykofarmakologi

Diakonhjemmet Sykehus

og

Avdeling for helsefag

Høgskolen i Oslo

\section{Lars Tanum*}

Seksjon for psykiatrisk forskning og undervisning Diakonhjemmet Sykehus

\section{Helge Refsum}

Senter for psykofarmakologi

Diakonhjemmet Sykehus

\author{
* Nåværende adresse: \\ Avdeling for forskning \& utvikling psykisk \\ helsevern
}

Akershus universitetssykehus

I Felleskatalogen er doseringen av legemidler oppgitt uten differensiering basert på pasientens kjønn. Dette til tross for at det for en del medikamenter er påvist farmakokinetiske forskjeller mellom kvinner og menn. Farmakokinetisk variabilitet av et legemiddel kan følges ved å måle konsentrasjonen av legemidlet i serum. For flere selektive serotoninreopptakshemmere er det rapportert høyere serumkonsentrasjoner hos kvinner enn hos menn (1-5). Serumkonsentrasjonen er et indirekte mål på konsentrasjon av et legemiddel på virkestedet. For noen psykofarmaka er det påvist en klar sammenheng mellom serumkonsentrasjon og klinisk effekt/bivirkninger, mens det for de fleste andre psykofarmaka kun er etablert et tentativt konsentrasjonsområde (6).

Farmakokinetisk variabilitet skyldes forskjeller i absorpsjon, distribusjon, metabolisme og ekskresjon. Cytokrom P-450 (CYP)-enzymer i lever og tarm er involvert i metabolisme av mange legemidler. Variabel aktivitet av CYP-enzymene, forårsaket av for eksempel genetiske forhold eller miljøfaktorer som røyking, kosthold og legemiddelinteraksjoner, er en viktig årsak til individuelle forskjeller i farmakokinetikk av legemidler. Enkelte CYP-enzymer har vist ulik aktivitet hos menn og kvinner (7), og det er holdepunkter for at aktiviteten kan påvirkes av alder (8).

Hensikten med studien var å undersøke kjønns- og aldersforskjeller i dosering og serumkonsentrasjon av psykofarmaka. Videre var det ønskelig å undersøke i hvilken grad eventuelle farmakokinetiske forskjeller ble tatt hensyn til ved dosejustering i klinisk praksis. Studien ble utført ved Senter for psykofarmakologi, Diakonhjemmet Sykehus, og er en naturalistisk undersøkelse av blodprøver tatt som del av klinisk oppfølging av psykiatriske pasienter.

\section{Materiale og metode}

Alle blodprøver mottatt ved Senter for psykofarmakologi, Diakonhjemmet Sykehus, i perioden 22.11. 2004-12.1. 2005, der det var rekvirert serumkonsentrasjonsanalyse av ett eller flere antidepressiver (ATC-gruppe N06A) eller antipsykotika (N05A), ble inkludert $\mathrm{i}$ studien. En del av disse pasientene fikk i tillegg antiepileptika (N03A). Opplysninger om dosering, alder, kjønn og om pasienten var inneliggende eller poliklinisk ble hentet fra rekvisisjonen, og målte serumkonsentrasjoner ble registrert.

Blodprøvene ble tatt på glass uten tilsetning og etter prøveopparbeidelse (proteinfelling) ble de analysert ved hjelp av høytrykks væskekromatografi med tandem massespektrometer-deteksjon (HPLC-MS/MS).

Prøver fra i alt 28 pasienter ble ekskludert fordi dosering ikke var oppgitt eller fordi det ikke ble påvist legemiddel ved analysen. For fire pasienter var det sendt inn mer enn en blodprøve i tidsperioden. I disse tilfeller ble kun data fra den først innsendte blodprøven inkludert i studien.

Dosering av et gitt legemiddel ble regnet om til antall definerte døgndoser (DDD) (9). For pasienter som brukte flere legemidler innen samme psykofarmakagruppe (dvs. antidepressiver, antipsykotika eller antiepileptika), ble antall DDD summert til totalt antall DDD. For å beskrive serumkonsentrasjon av ulike psykofarmakagrupper uavhen-

\section{Hovedbudskap}

- Eldre kvinner ( $\geq 65$ år) hadde høyere dosejustert serumkonsentrasjon av antidepressiver enn jevnaldrende menn og yngre pasienter av begge kjønn.

- Forskjellen i farmakokinetikk var kun delvis tatt hensyn til i klinisk praksis ved å gi eldre kvinner lavere doser av antidepressiver

- Antidepressiver og antipsykotika ble dosert høyere enn WHOs definerte døgndoser 
gig av hvilket legemiddel pasienten fikk, ble det beregnet en referanseindeks (RI) basert på målt serumkonsentrasjon og laboratoriets referanseområde for det enkelte legemidlet. RI ble beregnet som serumkonsentrasjon dividert på middelverdien i referanseområdet. Dette gir $\mathrm{RI}=1,0$ ved en serumkonsentrasjon midt i referanseområdet. For å sammenlikne farmakokinetikk i ulike pasientgrupper ble dosejustert referanseindeks (DRI) beregnet ved å dividere RI på antall DDD pasienten fikk forskrevet.

Hver enkelt blodprøve ble brukt som tellende observasjon. Gjennomsnittlig antall DDD, RI og DRI ble sammenliknet mellom menn og kvinner og ulike aldersgrupper. Ved deskriptiv statistikk ble gruppegjennomsnitt angitt som medianverdi og spredningen uttrykt ved 10-prosentilen og 90-prosentilen. Pasienter som var 65 år eller mer, ble klassifisert som eldre. Dette er den samme alderoppdelingen som mange produsenter bruker i Felleskatalogen. DRI-verdier ble også sammenliknet mellom polikliniske og hospitaliserte pasienter for å vurdere etterlevelse i disse pasientgruppene. PASW Statistics (versjon 18.0) ble benyttet for statistiske analyser. Spredningsdiagram (scatterplot) ble brukt for å illustere sammenhengen mellom dosejustert serumkonsentrasjon og alder for de to kjønnene. Her ble det benyttet PASW Statistics standardprosedyre for ikkelinære regresjonslinjer: Loess med Epanechnikov kernel. Den ikke-parametriske Mann-Whitneys U-test ble benyttet ved sammenlikning av to avhengige grupper, mens Kruskal-Wallis test ble brukt dersom mer enn to grupper ble sammenliknet. Ved signifikant Kruskal-Wallis ble det gjort post hoc-testing mellom gruppene med MannWhitneys test, der signifikansnivået var Bonferroni-korrigert for multiple tester.

For analyse av prediktiv effekt på serumkonsentrasjon av henholdsvis alder, kjønn og om pasienten var hospitalisert, ble det benyttet en lineær regresjonsmodell. Siden avhengig variabel ikke var normalfordelt, ble data for denne ln-transformert før analyse. Signifikansnivå ble satt til $5 \%$. Serumverdier mer enn tre standardavvik over gjennomsnitt ble utelukket fra de statistiske analysene fordi dette i hovedsak var overdosetilfeller der eksakt dosering ofte var ukjent. Studien ble tilrådet av regional komité for medisinsk forskningsetikk (Øst-Norge, REK I).

\section{Resultater}

Serum fra 1553 pasienter ble inkludert i studien. Av disse var $57 \%$ kvinner, $65 \%$ var polikliniske prøver og gjennomsnittsalderen var 42 år (10-/90-prosentiler 25-66 år). Prøvene var innsendt fra fastleger (47\%), sykehusavdelinger (33\%), psykiatriske poliklinikker (13\%) og avtalespesialister i psykiatri $(5 \%)$. Det ble brukt 15 ulike antipsykotika og 11 ulike antidepressiver i den studerte pasientpopulasjonen. De mest brukte antipsykotika var olanzapin, quetiapin, ris- peridon og klozapin. Blant antidepressivene var escitalopram hyppigst anvendt, etterfulgt av venlafaksin, mirtazapin og citalopram. Lamotrigin var vanligste antiepileptikum, etterfulgt av valproat og klonazepam. $61,5 \%$ av pasientene brukte ifølge rekvisisjonen kun ett psykofarmakum, mens $27,0 \%$ brukte to og $11,5 \%$ brukte tre til fem forskjellige psykofarmaka.

\section{Dosering av psykofarmaka}

Mediant antall DDD av psykofarmaka var $1,6(0,7-3,7)$. Høyest dosert var sertralin $($ median $=2,0$ DDD $)$, fluoksetin $($ median $=$ 1,8 DDD) og venlafaksin (median =1,5 DDD). Inndelt etter psykofarmakagruppe var median dosering 1,5 DDD for antidepressiver, 1,2 DDD for antipsykotika og 0,5 DDD for antiepileptika.Totalt antall DDD av psykofarmaka var noe høyere hos menn enn hos kvinner (median 1,8 mot 1,5 DDD), men forskjellen var ikke signifikant. Antipsykotika ble dosert signifikant høyere hos menn enn kvinner (median 1,4 mot 1,0; $\mathrm{p}=0,02$ ), mens dosering av antidepressiver og antiepileptika ikke var signifikant forskjellig mellom kjønnene.

Totalt antall DDD av psykofarmaka var signifikant lavere blant pasienter som var 65 år eller eldre sammenliknet med yngre pasienter (median 1,4 mot 1,8 DDD; $\mathrm{p}<0,01$ ). Eldre fikk signifikant lavere dose av antidepressiver og antipsykotika, men ikke av antiepileptika.

\section{Serumkonsentrasjoner (referanseindeks)}

Pasienter som brukte antidepressiver hadde median referanseindeks (RI) på 0,7 (10/90prosentiler: $0,2-1,8)$, det vil si en serumkonsentrasjon noe under midten av referanseområdet. Median RI for antipsykotika var 0,8 (10-/90-prosentiler: 0,2 til 2,0) og for antiepileptika 0,6 (10-/90-prosentiler: 0,2 til 1,1).
Kvinner hadde signifikant høyere median RI av antidepressiver enn menn $(0,8$ mot $0,6 ; p=0,01)$, mens det ikke var noen klar forskjell for antipsykotika og antiepileptika.

Pasienter som var 65 år og eldre hadde signifikant høyere gjennomsnittlig RI av antidepressiver enn yngre pasienter $(1,2 \mathrm{mot}$ $0,8 ; \mathrm{p}<0,01)$, mens RI av antipsykotika og antiepileptika ikke var signifikant forskjellig for eldre og yngre pasienter. Som illustrert $\mathrm{i}$ figur 1 , hadde eldre kvinner signifikant høyere RI av antidepressiver enn både menn og kvinner under 65 år.

Eldre kvinner fikk i snitt signifikant lavere dosering av fem av de åtte mest brukte enkeltpreparatene sammenliknet med resten av studiepopulasjonen, men median serumkonsentrasjon var høyere hos kvinner $\geq 65$ år for alle de mest brukte antidepressivene. For mirtazepin var serumkonsentrasjonen signifikant høyere hos eldre kvinner, selv om median dosering var den samme som hos resten av pasientene (tab 1).

\section{Dosejusterte referanseindekser (DRI)}

Eldre kvinner hadde statistisk signifikant høyere gjennomsnittlig dosejustert referanseindeks (DRI) av antidepressiver enn menn i samme aldersgruppe og pasienter av begge kjønn under 65 år $(\mathrm{p}<0,01)$. Samme dose antidepressiver ga i gjennomsnitt eldre kvinner over dobbelt så høy serumkonsentrasjon som pasientene i de tre andre gruppene. Siden kvinner i snitt lever lenger enn menn, kunne dette funnet skyldes en alderseffekt. Kvinnene i gruppen $\geq 65$ år er imidlertid bare marginalt eldre enn mennene i samme gruppe: aritmetisk gjennomsnitt var 76,8 år for kvinnene og 75,4 år for mennene (medianverdier 76 år mot 75 år). Forskjellen er ikke signifikant, men for ytterligere å analysere alder og kjønn som prediktor for DRI av antidepressiver ble

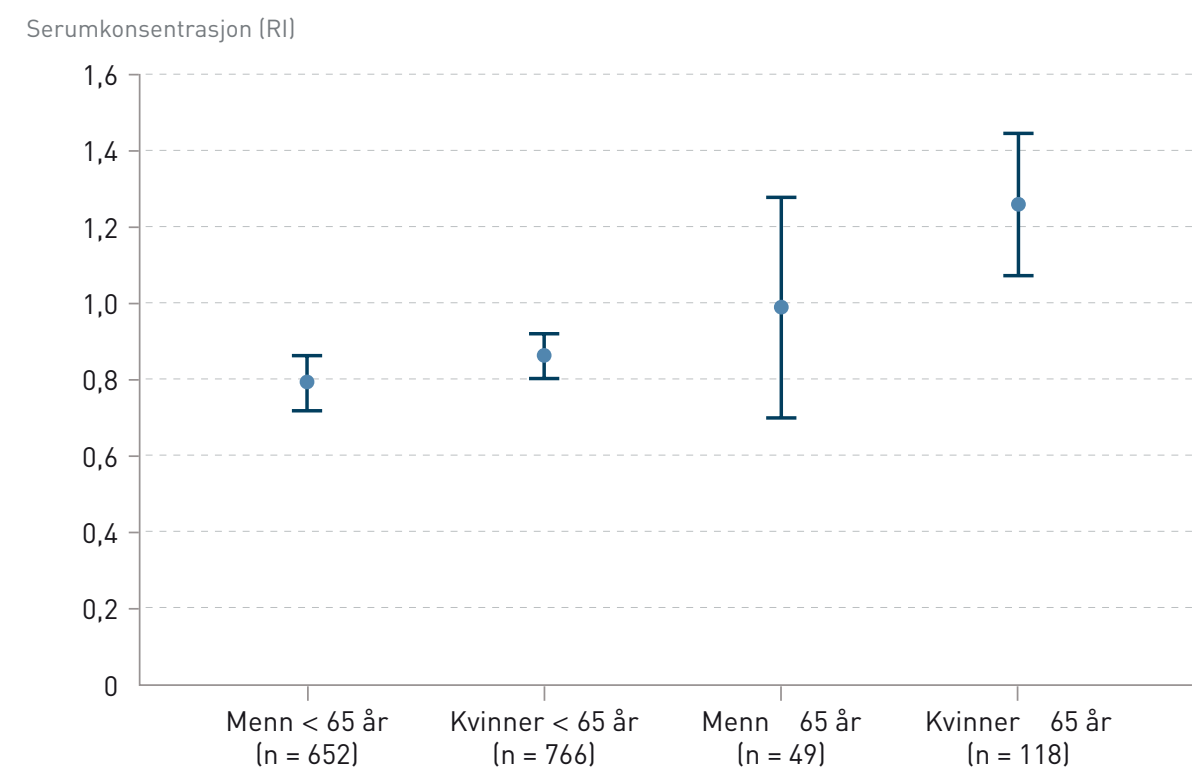

Figur 1 Serumkonsentrasjon (RI) av antidepressiver. Gjennomsnitt (med $95 \%$ konfidensintervall) for fire pasientgrupper. $R /=$ referanseindeks basert på målt serumkonsentrasjon dividert på middelverdien i referanseområdet 


\begin{tabular}{|c|c|c|c|c|c|c|}
\hline \multirow[b]{2}{*}{ Legemiddel (antall) } & \multicolumn{3}{|c|}{ Dose (mg) } & \multicolumn{3}{|c|}{ Serumkonsentrasjon (nmol/l) } \\
\hline & $\begin{array}{l}\text { Kvinner } \\
\geq 65 \text { år }\end{array}$ & $\begin{array}{c}\text { Alle } \\
\text { andre }\end{array}$ & P-verdi & $\begin{array}{l}\text { Kvinner } \\
\geq 65 \text { år }\end{array}$ & $\begin{array}{l}\text { Alle } \\
\text { andre }\end{array}$ & P-verdi \\
\hline \multicolumn{7}{|l|}{ Antipsykotika } \\
\hline Olanzapin (21/234) & 10 & 15 & $<0,01$ & 99 & 105 & 0,58 \\
\hline Quetiapin (11/141) & 175 & 600 & $<0,01$ & 54 & 241 & 0,18 \\
\hline Risperidon (8/138) & 2 & 5 & 0,37 & 61 & 48 & 0,15 \\
\hline Klozapin (4/138) & 25 & 400 & $<0,01$ & 357 & 1053 & 0,17 \\
\hline \multicolumn{7}{|l|}{ Antidepressiver } \\
\hline Escitalopram (19/234) & 10 & 15 & 0,02 & 56 & 45 & 0,06 \\
\hline Venlafaksin (14/172) & 150 & 150 & 0,98 & 1896 & 1031 & 0,09 \\
\hline Mirtazapin (20/88) & 30 & 30 & 0,18 & 199 & 129 & $<0,01$ \\
\hline Citalopram (12/79) & 20 & 40 & $<0,01$ & 226 & 163 & 0,12 \\
\hline
\end{tabular}

det foretatt regresjonsanalyse. I denne ble DRI av antidepressiver brukt som avhengig variabel, mens alder og kjønn var uavhengige variabler. Regresjonsmodellen var signifikant (ved ANOVA-test, $\mathrm{p}<0,01$ ), og både alder $(\mathrm{B}=0,006 ; \mathrm{p}<0,01)$ og kjønn $(\mathrm{B}=$ $0,08 ; \mathrm{p}<0,01)$ bidro signifikant til å forklare varians i DRI for antidepressiver. Dersom et interaksjonsledd med aldersgruppe*kjønn legges til modellen, forblir alder og kjønn signifikante prediktorer, og i tillegg er interaksjonen signifikant $(\mathrm{B}=0,20 ; \mathrm{p}<0,01)$. Som det fremgår av figur 2, er DRI høyere for kvinner enn menn i begge aldersklasser, men kjønnsforkjellen er mest markant for de eldste pasientene.

Gjennomsnittlig DRI av antidepressiver var statistisk signifikant høyere hos hospitaliserte pasienter enn hos polikliniske pasien-

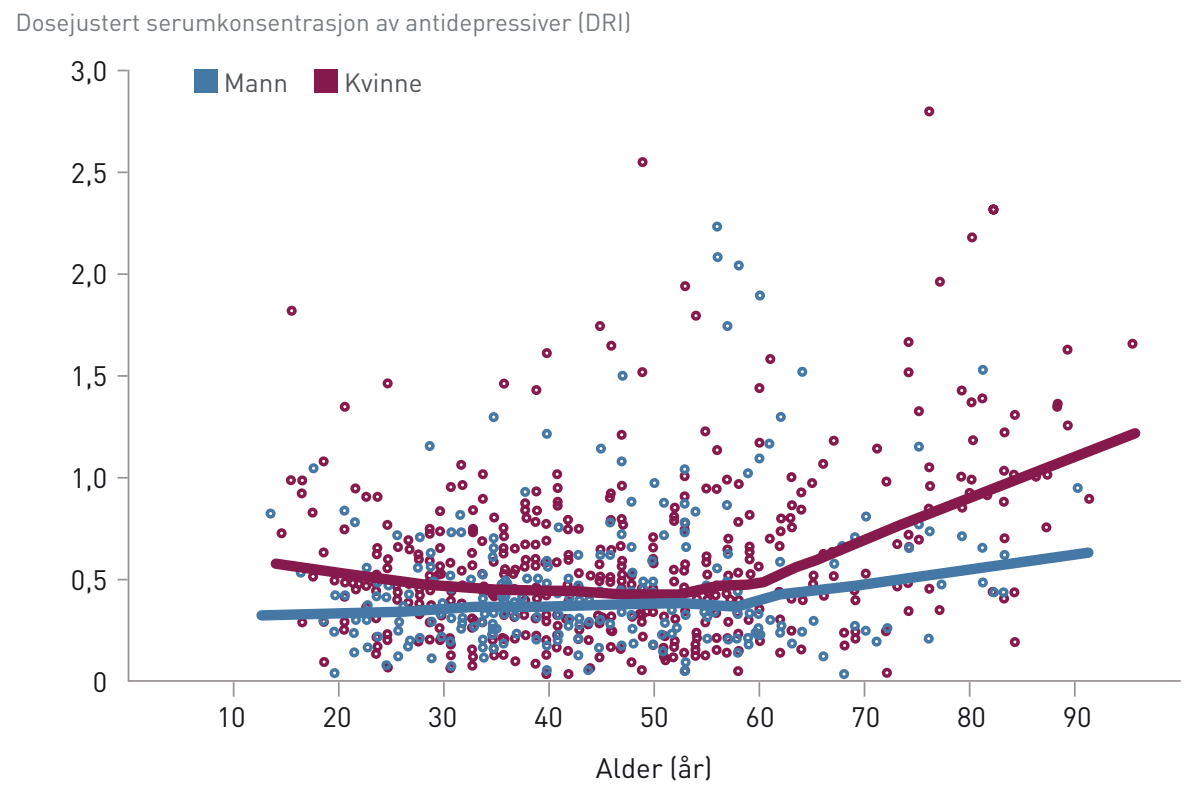

Figur 2 Dosejustert referanseindeks (DRI) av antidepressiver som funksjon av alder og kjønn. DRI = referanseindeks (RI) dividert på dosering (målt i antall DDD) dosejustert serumkonsentrasjon av antidepressiver enn eldre menn ( $\geq 65$ år) og yngre pasienter av begge kjønn. Dette er $\mathrm{i}$ overensstemmelse med en tidligere norsk studie der serumkonsentrasjon av flere antidepressiver ble rapportert å være signifikant høyere hos kvinner og hos eldre pasienter sammenliknet med menn og yngre pasienter (5). Studiene tyder på en endret farmakokinetikk av antidepressiver hos eldre kvinner. Selv om kvinnene i aldersgruppen $\geq 65$ år var noe eldre enn menn i samme gruppe, tyder regresjonsanalysen på at både alder og kjønn har betydning for funnet.

Aldring innebærer fysiologiske forandringer som kan påvirke distribusjon av legemidler, f.eks. endret fettprosent, muskelmasse og kroppsvekt. Kjønnseffekten kan ha sin årsak i endret distribusjon som følge av for eksempel redusert kroppsvekt. Selv om vi i denne studien ikke har målt pasientenes kroppsvekt, vet man at menn i snitt veier $16-17 \%$ mer enn like gamle kvinner (10). Vekten faller i begge kjønn fra omtrent 60 års alder, og dette sammen med lavere eliminasjon forårsaket av redusert aktivitet av legemiddelmetaboliserende enzymer, dårligere nyrefunksjon eller redusert blodgjennomstrømning i leveren (11) kan medvirke til alderseffekten. Større grad av komorbiditet kan være en annen forklaring på høyere serumkonsentrasjoner hos eldre pasienter. Komorbiditet kan i seg selv gi redusert eliminasjon av legemidler og innebærer i tillegg risiko for legemiddelinteraksjoner pga. polyfarmasi.

I den studerte pasientpopulasjonen var dosering av antidepressiver lavere hos eldre kvinner enn hos andre pasienter. Dosereduksjonen kompenserte imidlertid ikke fullt ut for den endrede farmakokinetikken, da serumkonsentrasjonen var høyere hos de eldre kvinnene. Tidligere studier har vist at kvinner har 50-70\% høyere risiko enn menn for bivirkninger (12). Mange av de vanlige bivirkningene av antidepressiver er avhengige av serumkonsentrasjon (13-15). Funnene i denne studien tyder på at høyere serumkonsentrasjon kan være en av årsakene til at eldre kvinner opplever mer bivirkninger av antidepressiver enn andre pasientgrupper.

Pasientene i studien fikk gjennomgående høyere doser av antidepressiver og antipsykotika enn WHOs definerte døgndoser. For noen preparater var den gjennomsnittlige doseringen to definerte døgndoser, i tillegg brukte nesten $40 \%$ av pasientene to eller flere psykofarmaka. Dette kan skyldes at pasienter som får målt serumkonsentrasjon, ikke er representative for hele pasientpopulasjonen som bruker legemidlene. Over halvparten av prøvene i studien var fra pasienter som ble behandlet i spesialisthelsetjenesten, og det kan ikke utelukkes at det har vært seleksjonsskjevhet i retning pasienter som på grunn av sykdommens alvorlighetsgrad har behov for spesielt høye doser. Det kan også tenkes at serumkonsentrasjonsmålinger, som blant annet utføres for å forhindre overdose- 
ring, foretas oftere hos pasienter som bruker høye doser psykofarmaka.

Et naturalistisk materiale har både svakheter og styrker i forhold til kontrollerte kliniske studier. Ved utprøving av legemidler utelukkes ofte pasientgrupper som eldre og pasienter med komedikasjon eller komorbiditet. Funn fra velkontrollerte studier kan derfor være vanskelig å generalisere til pasienter i den kliniske hverdagen, og naturalistiske studier av populasjonen som bruker legemidlet kan gi verdifull tilleggskunnskap. På den annen side kan komorbiditet, komedikasjon, og seleksjonsskjevhet påvirke resultatene i naturalistiske studier. Manglende kontroll med etterlevelse er også et problem $(16,17)$. I denne studien hadde pasienter som var innlagt i sykehus, der kontrollen av etterlevelse antas å være god, høyere dosejustert referanseindeks for antidepressiver enn de polikliniske pasientene. Dette er overensstemmelse med en tidligere studie for olanzapin (18), og kan tyde på at polikliniske pasienter tar lavere doser enn det legen har forskrevet. Funn fra regresjonsanalysen der alder, kjønn og hospitaliseringsstatus ble brukt som mulige forklaringsvariabler, tyder på at alle disse tre faktorene bidrar til å forklare varians i den dosejusterte serumkonsentrasjonen for antidepressiver.

\section{Konklusjon}

Kjønn og alder kan påvirke farmakokinetikken av psykofarmaka. Ved samme dose antidepressiver fikk eldre kvinner i gjennomsnitt dobbelt så høy serumkonsentrasjon som jevnaldrende menn og yngre pasienter av begge kjønn. Forskjellen i farmakokinetikk av antidepressiver var kun delvis tatt hensyn til i klinisk praksis ved å gi eldre kvinner lavere dose. Høyere serumkonsentrasjon er en mulig årsak til bivirkninger av antidepressiver hos eldre kvinner.

Følgende legemiddelfirmaer ga økonomisk støtte til studien: Lundbeck, Organon, Wyeth Lederle Norge og Eli Lilly Norge.

\section{Kjell Petter Bøgwald (f. 1956)}

er spesialist i psykiatri, dr.med. og avtalespesialist i Oslo. Tidligere overlege ved FoUavdelingen, Diakonhjemmet Sykehus. Ingen oppgitte interessekonflikter.

\section{Ida Rudberg (f. 1978)}

er farmasøyt ved Senter for psykofarmakologi. Hun har doktorgrad i farmakologi med farmakokinetikk og farmakogenetikk som spesialområder.

Ingen oppgitte interessekonflikter.

\section{Lars Tanum (f. 1956)}

er dr.med. og spesialist i psykiatri og klinisk farmakologi. Han er nå seniorforsker ved Avdeling for forskning \& utvikling psykisk helsevern, Akershus universitetssykehus

Oppgitte interessekonflikter: Forfatteren har mottatt konsulenthonorar fra Lundbeck, Eli Lilly, Bristol Myers Squibb og Glaxo-

SmithKline.

\section{Helge Refsum (f. 1947)}

er professor dr.med. og spesialist i klinisk farmakologi. Han arbeider som avdelingsoverlege og leder av Senter for psykofarmakologi ved Diakonhjemmet Sykehus.

Ingen oppgitte interessekonflikter.

\section{Litteratur}

1. Meibohm B, Beierle I, Derendorf H. How importan are gender differences in pharmacokinetics? Clin Pharmacokinet 2002; 41: 329-42.

2. Härtter S, Wetzel H, Hammes E et al. Nonlinear pharmacokinetics of fluvoxamine and gender differences. Ther Drug Monit 1998; 20: 446-9.

3. Ronfeld RA, Tremaine LM, Wilner KD. Pharmacokinetics of sertraline and its $\mathrm{N}$-demethyl metabolite in elderly and young male and female volunteers. Clin Pharmacokinet 1997; 32 (suppl 1): 22-30

4. Reis M, Lundmark J, Bengtsson F. Therapeutic drug monitoring of racemic citalopram: a 5-year experience in Sweden, 1992-1997. Ther Drug Monit 2003; 25: 183-91

5. Reis M, Aamo T, Spigset 0 et al. Serum concentrations of antidepressant drugs in a naturalistic setting: compilation based on a large therapeutic drug monitoring database. Ther Drug Monit 2009; 31: $42-56$.
6. Andersen S, Refsum H, Tanum L. Bruk av psykofarmaka - bør serumkonsentrasjonen kontrolleres? Tidsskr Nor Lægeforen 2004; 124: 2362-4.

7. Anderson GD. Sex and racial differences in pharmacological response: where is the evidence? Pharmacogenetics, pharmacokinetics, and pharmacodynamics. J Womens Health (Larchmt) 2005 14: 19-29.

8. Bebia Z, Buch SC, Wilson JW et al. Bioequivalence revisited: influence of age and sex on CYP enzymes. Clin Pharmacol Ther 2004; 76: 618-27.

9. WHO Collaborating Centre for Drug Statistics Methodology. ATC/DDD Index 2012 www.whocc.no/atc ddd index/ (19.4.2010)

10. Ogden $\mathrm{CL}$, Fryar CD, Carroll MD et al. Mean body weight, height, and body mass index, United States 1960-2002. Adv Data 2004; nr. 347: 1- 17.

11. Gross JL, Friedman R, Azevedo MJ et al. Effect of age and sex on glomerular filtration rate measured by 51Cr-EDTA. Braz J Med Biol Res 1992; 25: $129-34$.

12. Rademaker M. Do women have more adverse drug reactions? Am J Clin Dermatol 2001: 2: 349-51.

13. Vaswani M, Linda FK, Ramesh S. Role of selective serotonin reuptake inhibitors in psychiatric disorders: a comprehensive review. Prog Neuropsychopharmacol Biol Psychiatry 2003; 27: 85-102.

14. Fabre LF Jr, Abuzzahab FS, Amin M et al. Sertraline safety and efficacy in major depression: a double-blind fixed-dose comparison with placebo. Biol Psychiatry 1995; 38: 592-602.

15. Burke WJ, Gergel I, Bose A. Fixed-dose trial of the single isomer SSRI escitalopram in depressed outpatients. J Clin Psychiatry 2002; 63: 331-6.

16. Lingam R, Scott J. Treatment non-adherence in affective disorders. Acta Psychiatr Scand 2002 105: $164-72$

17. Demyttenaere K, Adelin A, Patrick M et al. Sixmonth compliance with antidepressant medication in the treatment of major depressive disorder. Int Clin Psychopharmacol 2008; 23: 36-42.

18. Castberg I, Westin AA, Spigset O. Does level of care, sex, age, or choice of drug influence adherence to treatment with antipsychotics? J Clin Psychopharmacol 2009; 29: 415-20.

Mottatt 25.11. 2010, første revisjon innsendt 14.4.2011, godkjent 3.11.2011. Medisinsk redaktør Jon Amund Kyte. 